\title{
Wintering shorebird in sandy coasts of Catania's gulf (Sicily, Italy): 2011-2020
}

\author{
Paolo Galasso $^{1 *}$, Dario Grimaldi², Letizia Aiello ${ }^{3}$, Gabriele Galasso ${ }^{4}$
}

\begin{abstract}
Sandy coasts are specific habitats of high ecological significance for many species of shorebirds. The Gulf of Catania, in the Eastern coast of Sicily, is considered one of the most important sandy coastal areas of the region for the wintering of different species of Charadriidae and Scolopacidae, also due to the presence of River Simeto's mouth and other freshwater streams. Since the area has been subject to many changes in the last few decades and recent data were not available, a ten-year monitoring of the wintering shorebird community has been carried out, from January 2011 to January 2020, to understand its current ecological role and to update the knowledge about numbers and trends of Sicilian wintering shorebirds along the coast. A total of 3,171 individuals and 16 different species were observed, including a considerable amount of individuals of Calidris alba and Charadrius alexandrinus, despite the latter showed an $80 \%$ decrease in number in the last 20 years in the area. For each species, maximum numbers observed per winter and related five-year averages, estimates, IKA (Index of Abundance per Kilometre) and percentages in relation to the national wintering population have been reported. Furthermore, data about species associations were collected and analysed. This survey shows how the ecological value of River Simeto's mouth has decreased considerably in the last decades in favour of other locations, such as the mouth of Canale Arci, where almost $50 \%$ of the birds were observed.
\end{abstract}

Key words: Charadrius alexandrinus, River Simeto's mouth, International Waterbird Census, Overwinter, Waders.

Riassunto - Limicoli svernanti nelle coste sabbiose del Golfo di Catania (Sicilia, Italia): 2011-2020.

I litorali sabbiosi sono habitat specifici di notevole valore ecologico per molte specie di limicoli. Il Golfo di Catania, situato lungo la costa centro-orientale della Sicilia, è considerato una delle aree costiere sabbiose più importanti della regione per lo svernamento di Charadriidae $\mathrm{e}$ Scolopacidae, soprattutto per la presenza della foce del Fiume Simeto e di altri sbocchi dulciacquicoli. Poiché l'area, nel corso degli ultimi

${ }^{1}$ Stiftung Pro Artenvielfalt $囚$, Meisenstraße 65, 33607 Bielefeld, Germany.

${ }^{2}$ Via Gaetano Donizetti 51, 95126 Catania, Italia.

${ }^{3}$ Via Luigi Cadorna 4, 31015 Conegliano (TV), Italia.

${ }^{4}$ Consorzio Nazionale Interuniversitario per le Scienze del Mare (CoNISMa), P.le Flaminio 9, 00196 Roma, Italia.

* Corresponding author: paolo_galasso@hotmail.com

(C) 2021 Paolo Galasso, Dario Grimaldi, Letizia Aiello, Gabriele Galasso

Received for publication: 15 January 2021

Accepted for publication: 4 March 2021

Online publication: 16 April 2021 decenni, è stata soggetta a diversi cambiamenti, è stato effettuato da gennaio 2011 a gennaio 2020 un monitoraggio della comunità di limicoli svernanti in quest'area, per comprenderne l'attuale ruolo ecologico e per aggiornare le conoscenze su numeri e trend dei principali limicoli svernanti lungo le coste siciliane. Un totale di 3171 individui e 16 specie diverse sono state osservate, compreso un contingente interessante di Calidris alba e Charadrius alexandrinus, nonostante quest'ultimo dimostri in quest'area un declino di circa $1{ }^{\prime} 80 \%$ negli ultimi 20 anni. Per ogni specie sono stati riportati i numeri massimi osservati per inverno e le relative medie quinquennali, le stime, l'IKA (Indice di Abbondanza Chilometrico) e la percentuale in relazione all'intera popolazione svernante nazionale. Inoltre, sono stati raccolti e analizzati dati sulle associazioni di specie diverse. L'indagine ha evidenziato come il valore ecologico della foce del Simeto sia notevolmente diminuito negli ultimi decenni a favore di altri siti minori, come la foce del Canale Arci, dove è stato osservato quasi il 50\% del totale degli individui contattati.

Parole chiave: Charadrius alexandrinus, foce del Simeto, censimenti IWC, svernamento, limicoli.

\section{INTRODUCTION}

Sicily is one of the richest Italian regions in wintering shorebirds (Zenatello et al., 2014) for its central position into the Mediterranean Sea and, mainly, due to its climatic conditions, which are very similar to those of the coast of North Africa. Although most of them use to overwinter in wetlands and saltpans, sandy coasts have an important ecological value as well: they are indeed used for foraging, resting and as stop-over areas (Chandler, 2009). The knowledge of bird's richness and abundance in sandy coastal areas could allow to better evaluate the role of these neglected ecosystems and, in case, to apply appropriate conservation strategies (Battisti, 2014). The Gulf of Catania is located in the Eastern coast of Sicily (Fig. 1A-1B) and includes one of the widest sandy coastal habitat of the region that extends for about 20 kilometres. It reaches from the south side of Catania's harbour, near the torrent named "Torrente Acquicella", to "Capo Campolato di Augusta", where the rocky coast of Syracuse's province begins. It also includes some freshwater stream mouths named, from north to south: Torrente Acquicella, Canale Forcile, Canale Arci/Fontanarossa, River Simeto, River Gornalunga and River San Leonardo (Fig. 1C). The coastline is represented by wide (15-30 up to more than 200 meters) and flat beaches of fine and clear sand, without relevant changes in the tide level (Fig. 2). The who- 
le area, but in particular River Simeto's mouth, has been considered in the past, one of Sicily and south of Italy's most important sites for the wintering of many species of shorebirds and, in general, for water birds (Massa, 1978; Iapichino \& Massa, 1989; Lo Valvo et al., 1993; Ciaccio \& Priolo, 1997; Corso, 2005). Despite the fact that about 11 kilometres of the coast are included in Natura 2000 as Special Area of Conservation (SAC ITA070001) and into the natural reserve "R.N.O. Foce del Simeto", the area has been subject to many changes in the last few decades, appearing now strongly anthropized, disturbed, eroded and the dune system with its related vegetation, has almost

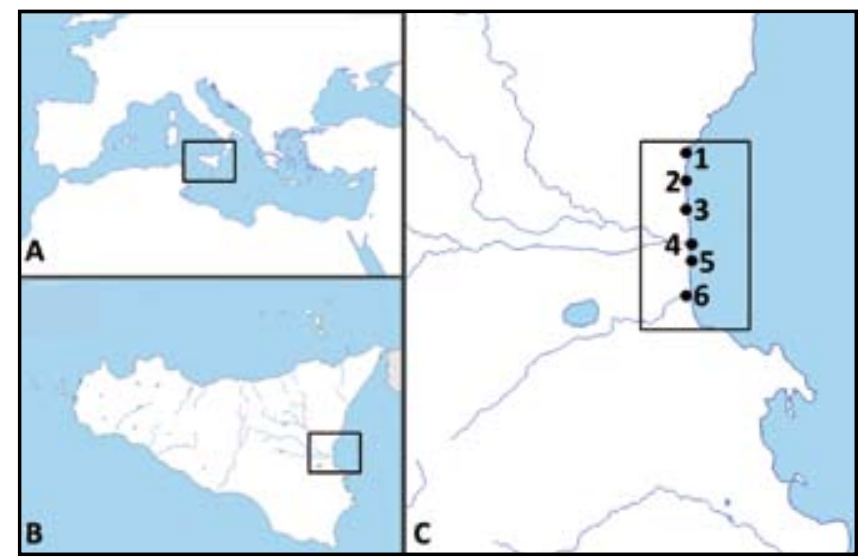

Fig. 1 - A-B) Geographic location of Catania's Gulf and C) main freshwater stream mouths. / A-B) Inquadramento geografico del Golfo di Catania e C) delle sue principali foci di corsi d'acqua dolce. 1) Acquicella, 2) Forcile, 3) Arci/Fontanarossa, 4) Simeto, 5) Gornalunga, 6) San Leonardo. totally disappeared. Given that only old and incomplete data were available, a study of the shorebirds community of Catania's Gulf was carried out, to understand its current ecological role and to update the knowledge about numbers and trends of wintering shorebirds along Sicilian coasts.

\section{STUDY AREA AND METHODS}

Monitoring and data collection followed the International Waterbird Census (IWC) directives, already used for the Italian national waterbird census (Serra et al., 1997; Baccetti et al., 2002; Zenatello et al., 2014). Data were collected on the field exclusively in the month of January, from Winter 2011 to 2020, using the line transects method (Bibby et al., 2000). After a first investigation of the whole sandy coast of Catania's Gulf in December 2010, the coastline was divided in 4 transects related to the most interesting stretches of coast to monitor, covering a total of 11 kilometres. The transects (selected depending on parameters as width of the beach, presence of freshwater streams, not excessive sources of disturbance, etc...) are listed and described below, from north to south:

- T1: beginning of sandy coast of Catania's Gulf, from Torrente Acquicella's mouth (3729'15.94'N; $\left.15^{\circ} 5^{\prime} 26.87^{\prime \prime} \mathrm{E}\right)$ to the south side of Canale Forcile's mouth $\left(37^{\circ} 28^{\prime} 15.24^{\prime \prime} \mathrm{N} ; 5^{\circ} 5^{\prime} 7.33^{\prime \prime} \mathrm{E}\right)$; about $2 \mathrm{~km}$ in total length;

- T2: from the stretch of beach named "Colonia Don Bosco" ( $\left.37^{\circ} 28^{\prime} 2.36^{\prime \prime} \mathrm{N} ; 5^{\circ} 5^{\prime} 7.50^{\prime \prime} \mathrm{E}\right)$ to the south side of

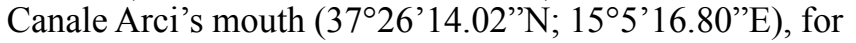
a total of $3.5 \mathrm{~km}$;

- T3: from the suburban area (village) named "Villaggio Paradiso degli Aranci” (37²5’22.96”N; 155'22.15”E)

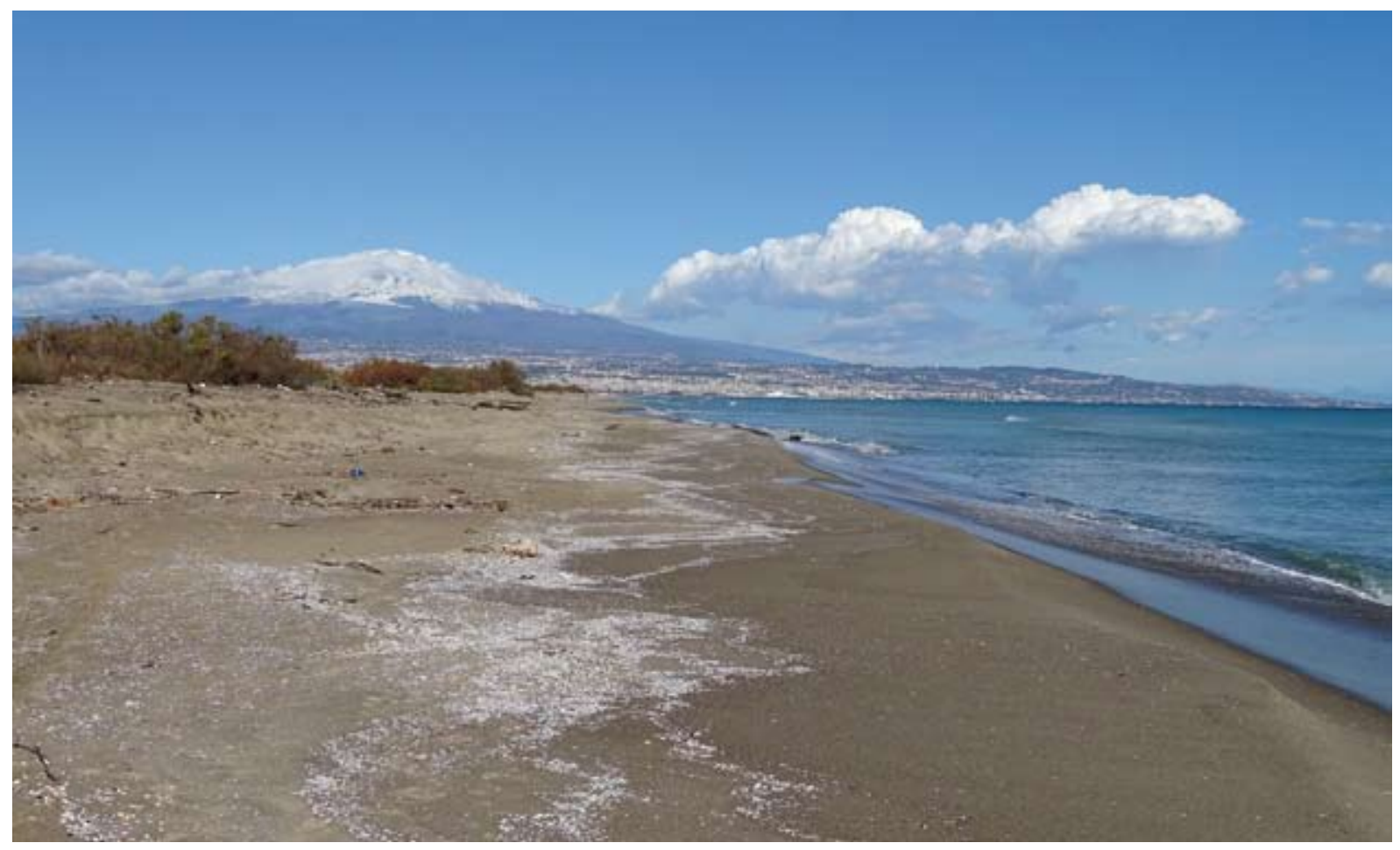

Fig. 2 - A typical streatch of sandy coast of Catania's Gulf, with Etna Mount on the background. / Tipico litorale sabbioso del Golfo di Catania, con l'Etna sullo sfondo. (Photo / Foto: D. Grimaldi). 
to Gornalunga's mouth $\left(37^{\circ} 23^{\prime} 9.18^{\prime \prime} \mathrm{N} ; 15^{\circ} 5^{\prime} 24.58^{\prime \prime} \mathrm{E}\right)$, including the mouth of River Simeto $\left(37^{\circ} 23^{\prime} 56.88^{\prime \prime} \mathrm{N}\right.$; $15^{\circ} 5^{\prime} 23.32^{\prime} \mathrm{E}$ ), for about $2.5 \mathrm{~km}$ in total. This stretch is included in the SAC ITA070001 and into the natural reserve "R.N.O. Foce del Simeto"; it is also included in the list of IWC (International Waterbird Census) Sicilian sites;

- T4: From the suburban area (village) named "Villaggio San Leonardo" (37²1'28.80”N; 155'28.25”E) to the beach of Agnone (37 $\left.19^{\prime} 49.14^{\prime \prime} \mathrm{N} ; 1^{\circ} 5^{\prime} 42.53^{\prime \prime} \mathrm{E}\right)$, including the mouth of River San Leonardo, for $3 \mathrm{~km}$ in total length.

Every transect was covered by two people at a time, at least three times a month (dates: 5, 22, 23, 29 and 30 January $2011 ; 8,19,22,25,27$ and 31 January 2012; 5, 13, 24, and 31 January 2013; 3, 11 and 23 January 2014; 4, 10 and 24 January $2015 ; 3,10$ and 17 January 2016; 1, 5, 14, 20 and 29 January 2017; 7, 13, 20, and 27 January 2018; $1,12,19$, and 27 January 2019; 4, 11, 18 and 25 January 2020), for a total of 41 surveys and about 164 hours on the field. Monitoring always started in the early morning, from 7:00 a.m. to no later than 12:30 a.m., with good weather conditions, walking along the shoreline and counting the shorebirds by means of telescopes and binoculars. To avoid recounting birds, individuals in flight were excluded from the counting. For every month/winter/year, only the maximum number of birds observed together was considered for the same transect; furthermore, individuals of the same species contacted at the same day, were added only if observed in not consecutive transects.

For the most abundant and regular wintering species was calculated the relative Index of Abundance per Kilometre (IKA, Bibby et al., 2000) and the percentage of local population (\%) in relation to the national wintering population estimate available for the period 2006-2010: if the species percentage is $\geq 1 \%$ the area can be considered as "reported site/site to report", and if the wintering population is $\geq 50$ individuals it can be therefore considered as "site of national importance" (Serra et al., 1997; Zenatello et al., 2014). Please note that the 4 transects monitored (11 km in total) will be considered as a single macro-area for the following data analysis (IKA calculation included), since they are quite short and characterized by very similar features. Statistical tests such as the Mann-Whitney U Test and the Chi Square's Test, commonly used in ornithology (Fowler \& Cohen, 2010), were applied to compare and analyse data series. Taxonomy utilized follows the checklist of Italian birds updated to 2019 (Baccetti et al., 2020). All the following numbers and estimates refer to wintering individuals, unless otherwise specified.

\section{RESULTS}

During the 10 years of this study 3,171 individuals were observed in total, belonging to 16 different shorebird species. Charadrius hiaticula, Charadrius alexandrinus, Calidris alba and Numenius arquata have been observed every winter, showing a high regularity of wintering; $P l u$ vialis squatarola, Calidris alpina, Calidris minuta, Gallinago gallinago, Actitis hypoleucos and Tringa totanus, were instead observed with a much lower frequency. Species as Haematopus ostralegus, Charadrius dubius, Cali- dris temminckii, Tringa erythropus and Tringa nebularia have been wintering occasionally/irregularly in the study area, and Tringa glareola was recorded only once. Here below are listed all the shorebird species observed, in order of frequency/overwinter-site regularity, between 2011 and 2020:

\section{Common Ringed Plover Charadrius hiaticula}

Observed every year in the study area, usually in small groups of 2-3 individuals (Fig. 3), often together with $C$. alexandrinus, mostly at the mouths of Canale Arci and River San Leonardo; 6 together on 10 January 2015 and on 27 January 2018. Estimate of 3-6 individuals for 2011-2015 and 2-6 for 2016-2020. Average of 3 individuals, both for 2011-2015 and 2016-2020; IKA (Index of Abundance per Kilometre) variable from a minimum of $0.09(2011,2019)$, up to a maximum of $0.5(2015,2018)$. Since the $1 \%$ of the national wintering population is fixed at least at 2 individuals (Zenatello et al., 2014), the study area hosted about the $1.6 \%$ of the Italian wintering population of Charadrius hiaticula during the period of study 2011-2020 and can be so considered as "site to report".

\section{Kentish Plover Charadrius alexandrinus}

Regularly observed every year, usually in groups of 10-20 individuals, mainly near freshwater stream mouths; very constant numbers through the years, with maximum of 23 individuals recorded in 2012 and exactly 22 observed in 2013, 2014, 2015 and 2017 as well. A peak of 51 was recorded on 10 January 2016: 31 together at River San Leonardo's mouth, Transect 4, and 20 at Canale Arci's mouth, Transect 2: these sites resulted the most important along the coastline of Catania's Gulf for

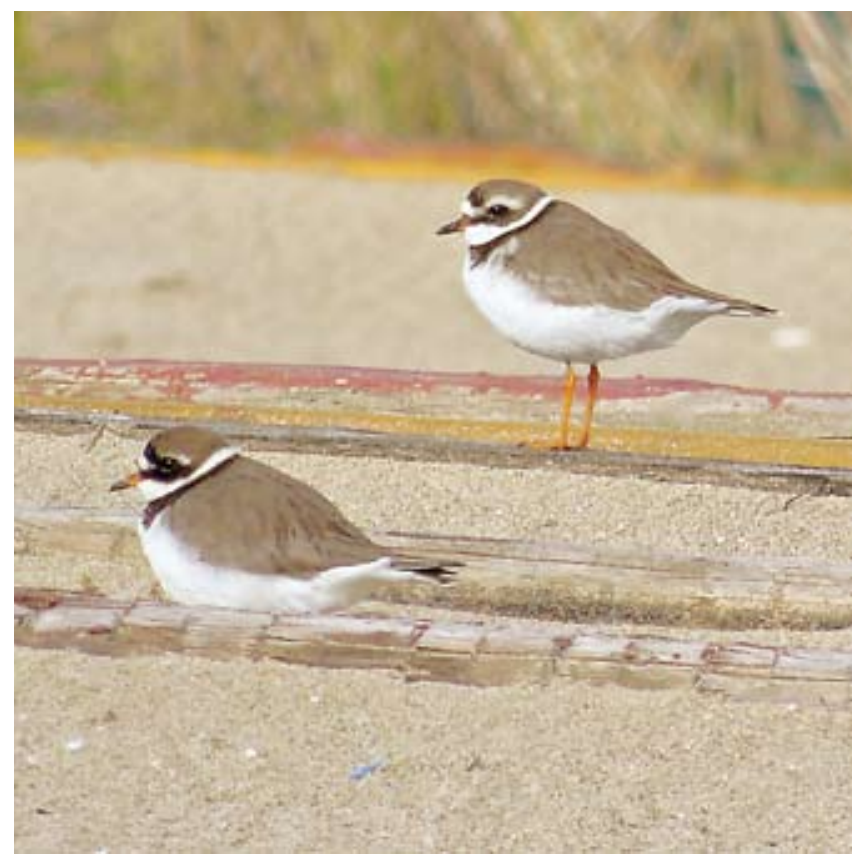

Fig. 3 - Common ringed plovers resting near to Canale Arci's mouth in January 2017. / Corrieri grossi a riposo nei pressi della foce del Canale Arci a gennaio 2017. (Photo / Foto: D. Grimaldi). 
this species. Estimate of 20-25 for 2011-2015 and 30-40 for 2016-2020, with an average respectively of 21 and 32. IKA variable from a minimum of 1.3 (2011) up to a maximum of 4.6 (2016). The study area hosted the $1.4 \%$ of the Italian wintering population during 2011-2015 and $2.1 \%$ for the period $2015-2020$, being the $1 \%$ fixed to 15 individuals (Zenatello et al., 2014) it can be considered as "site to report".

\section{Sanderling Calidris alba}

Observed every year in groups of 15-20 ind. (Fig. 4), mainly in the widest stretches of the sandy coast, often near the freshwater stream mouths; constant numbers through the years, most frequently with records of 24-28 ind.; unusually, only 8 were observed in January 2014. The estimation for 2011-2015 is of 20-28 ind. and 20-30 for 2016-2020, with a constant average respectively of 22 and 23. IKA variable from a minimum of 0.7 (2014), up to a maximum of 2.5 (2018). As already discussed from other authors (Iapichino \& Massa, 1989; Lo Valvo et al., 1993; Serra et al., 1997; Baccetti et al., 2002), Catania's Gulf represents an important area for the wintering of Calidris alba in Italy: indeed, the local population represented the $4.4 \%$ for $2011-2015$ and $4.6 \%$ for $2016-2020$ of the national wintering population, where the $1 \%$ is fixed to 5 individuals (Zenatello et al., 2014), and the study area can then be considered as "site to report".

\section{Eurasian curlew Numenius arquata}

Observed every winter in a single group of 25-40 ind. (Fig. 5), always in the same stretch of the beach (Playa Catania - Colonia Don Bosco, 37²7'55.26”N; $\left.15^{\circ} 5^{\prime} 7.06^{\prime} \mathrm{E}\right)$, used for feeding and resting in the early morning. It is probable that the flock is used to move from the sandy coastline to the internal fields of Catania's International Airport and vice versa. Quite variable numbers through the years, from a minimum of 10 in 2014 up to 67 , just the next year, in 2015. Estimation for 2011-2015 of 25-45 individuals with an average of 35 and 30-50 for 2016-2020 with an average of 38. IKA variable from 0.9 (2014) up to a 6.09 (2015). Since the $1 \%$ of the national wintering population is fixed to 73 individuals, (Zenatello et al., 2014), the area hosted a really low percentage, with values lower than $1 \%$.

\section{Grey plover Pluvialis squatarola}

Observed for seven winters, usually in small groups of 2-4 ind., mainly in the second part of the decade; none observed in 2012-2013 and in 2015. Estimation for 20112015 of 1-5 ind. and 2-7 ind. for 2016-2020, with averages respectively of 2 (1.6) and 5 (4.6). Very low IKA, from $0(2012-13,2015)$ to a maximum value of 0.63 (2019-20). The $1 \%$ of the national wintering population is fixed to 55 individuals (Zenatello et al., 2014), therefore the area hosted a really low percentage.

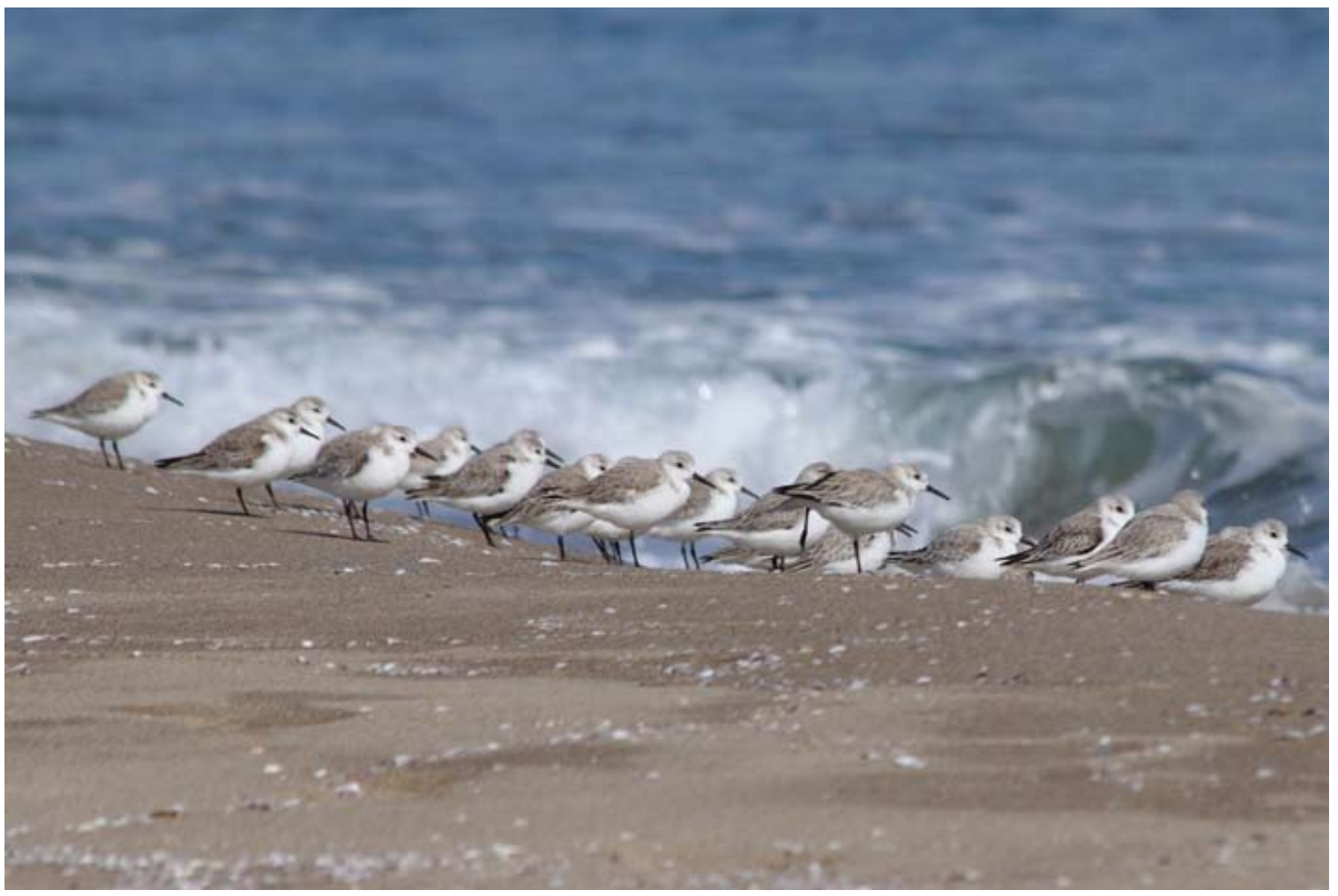

Fig. 4 - Flock of Sanderling photographed in January 2015. / Gruppo di piovanelli tridattilo fotografato a gennaio 2015. (Photo / Foto: P. Galasso). 


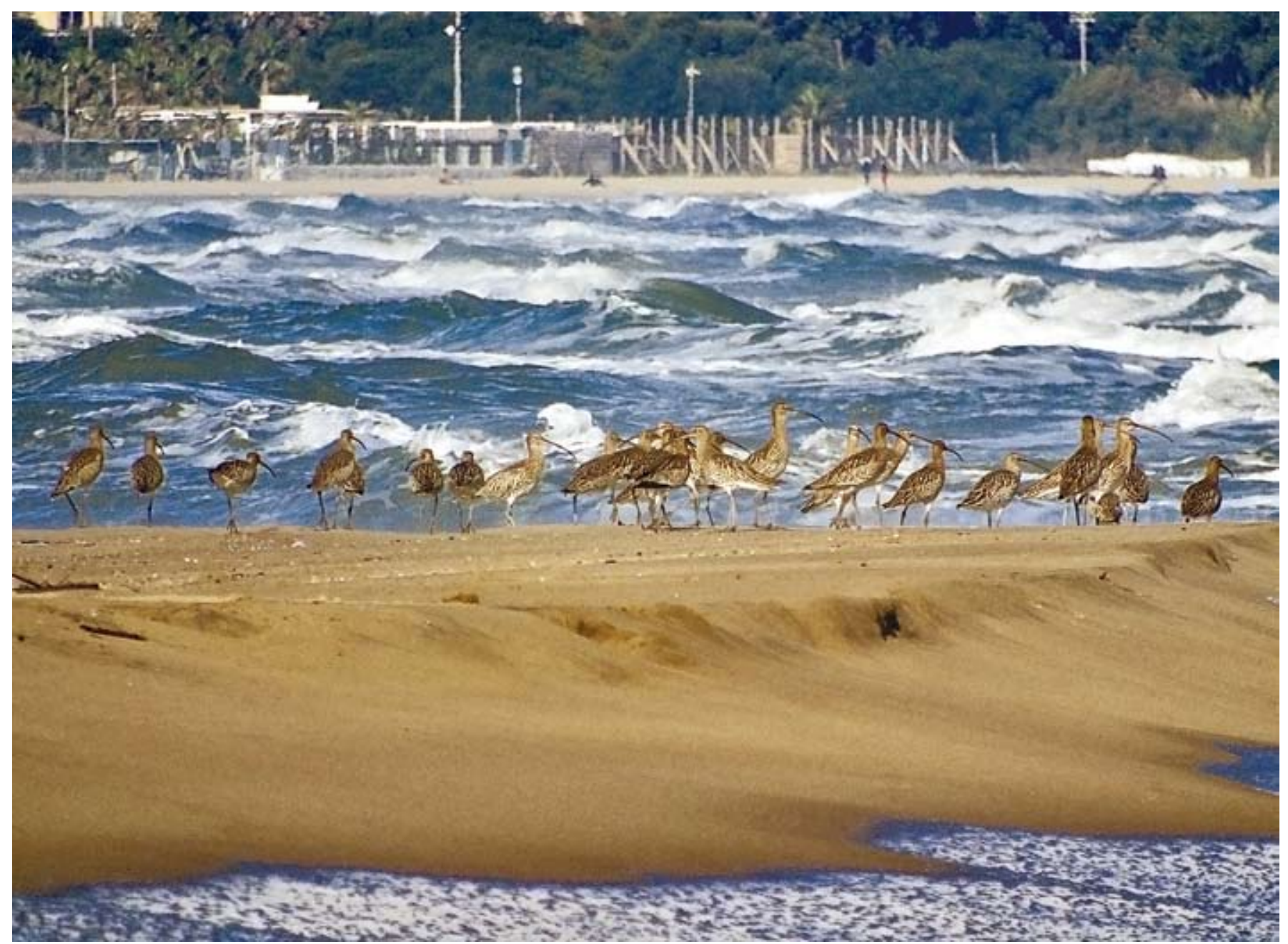

Fig. 5 - Flock of Eurasian curlew photographed in January 2019. / Gruppo di chiurli maggiori fotografato a gennaio 2019. (Photo: / Foto: D. Grimaldi).

\section{Dunlin Calidris alpina}

Observed six winters out of ten, in groups of 10-15 ind. always together with Calidris alba. None observed in 2014, 2016 and 2019-20. Its presence along the sandy shoreline during the winter is probably related to rainfalls in the area. Average of 10 ind. for 2011-2015 and 7 for 2016-2020. IKA from $0(2014,2016,2019$ and 2020) to a maximum of 2 (2018). Percentage much lower than $1 \%$, in relation to the national wintering population, being the $1 \%$ fixed to 754 individuals (Zenatello et al., 2014).

\section{Little Stint Calidris minuta}

Its presence is inconstant, it was observed in five winters exclusively in the first part of the decade 2011-2015, with few ind. always together with Calidris alba and Charadrius alexandrinus, mainly at the mouths of S. Leonardo and Canale Arci. Average of 3 (2.6) ind. for the period 2011-2015, 0 for 2016-2020. IKA from 0 (2016-2020) up to a maximum of 0.36 (2014). Percentage much lower than $1 \%$, in relation to the national wintering population, being $1 \%$ fixed to 20 individuals (Zenatello et al., 2014). The same irregular presence of 1-5 ind. was reported for the study area for the years 1980-1997 (Ciaccio \& Priolo, 1997).

\section{Common Snipe Gallinago gallinago}

Observed in five winters with only few individuals: 1 on 10 January 2015,1 on 10 January 2016,1 on 27 January 2018, 4 on 12 January 2019 and 4 on 25 January 2020. Annual average of 0.2 for the period 2011-2015, 2 for 2016-2020; maximum IKA of 0.36 (2019-20). Local wintering population's percentage much lower than $1 \%$ of the national one, fixed at least at 30 individuals (Zenatello et al., 2014).

\section{Common Sandpiper Actitis hypoleucos}

Its presence is inconstant, with only a few ind. observed in six winters: 1 for 2011, 2015, 2017, 2018 and 2019; 2 recorded in 2020. Observed exclusively near to Torrente Acquicella and River Simeto's mouth. Average lower than 1 (0.2) for the period 2011-2015, 1 for 2016-2020; maximum IKA of 0.18 (2020). The observed wintering population was much lower than $1 \%$ of the national one, fixed at least at 4 individuals (Zenatello et al., 2014).

\section{Redshank Tringa totanus}

Inconstant species with only a few ind. observed in six winters: 1 for January 2011 and 2014, 24 to- 
gether at Simeto's mouth on 21 January 2015, 3 for January 2016, 1 in January 2017 and 4 for 2018. Mainly observed at Simeto and Acquicella's mouths. Average of 5 for the period 2011-2015 and 2 (1.6) for 2016-2020; maximum IKA of 2.18 (2015). Wintering population's percentage much lower than $1 \%$ of the national one, fixed at least at 33 individuals (Zenatello et al., 2014).

\section{Little Ringed Plover Charadrius dubius}

Inconstant presence, observed only in three winters exclusively in the Transect 1, around the Acquicella's mouth: 2 in January 2015, 1 for January 2017 and 4 together on 19 January 2019. Larger groups were observed in December: 4 on 23 December 2018 and 5 on 3 December 2017. Estimate of 0-2 for 2011-2015 and 1-5 for 2016-2020 for the study area, with a relative average of 0.5 and 1 ; maximum IKA of 2.75 for 2019 . Wintering population's percentage represented more than $1 \%$ of the national one, being fixed at least at 1 individual (Zenatello et al., 2014) and the study area can be considered as "site to report".

\section{Eurasian Oystercatcher Haematopus ostralegus}

Only 1 individual observed for three winters, in January 2011 (at the Acquicella's mouth), 2012 (River Simeto's mouth) and 2013 (beach of Colonia Don Bosco): it was always the same subject, recognizable by a slight malformation in one leg (Galasso et al., 2013). Average of 0.6 for 2011-2015, there were no other individuals recorded after January 2013.

\section{Spotted Redshank Tringa erythropus}

Recorded only in two winters: 8 ind. together observed at the River Simeto's mouth several times in January 2018 and 5 in January 2020.

\section{Common Greenshank Tringa nebularia}

Recorded only in two winters: 4 ind. together observed at the River Simeto's mouth on different days in January 2018 and 2 in January 2020 at the River San Leonardo's mouth.

\section{Temminck's Stint Calidris temminckii}

Observed only in three winters but with interesting numbers: 4 together on 7 January 2018, 5 on 12 January 2019 and 5 on 25 January 2020, always at the Acquicella's mouth.

\section{Wood Sandpiper Tringa glareola}

Recorded only once: 3 ind. together observed while feeding on 25 January 2020 at the mouth of Canale Forcile.

In the Table 1, are listed all the species and their relative estimations and annual averages.

\section{OTHER SPECIES}

In addition to the ones in the list, other species observed exclusively in December are briefly mentioned here below:

\section{Eurasian Golden Plover Pluvialis apricaria}

- 1 ind. probably injured/debilitated, observed on 6 December 2015 along the shoreline between Canale Arci and Canale Forcile's mouths.

\section{Bar-tailed Godwit Limosa lapponica}

- 2 ind. together observed at the Acquicella's mouth on 7 December 2013.

Ruddy Turnstone Arenaria interpres

- 1 ind. feeding along the shoreline on 6 December 2015, near Canale Forcile's mouth.

\section{DISCUSSION}

The sandy coast of Catania's Gulf represented, in the period 2011-2020, an important wintering-site in Sicily for Charadrius dubius, Charadrius hiaticula, Charadrius alexandrinus, Calidris alba and Calidris minuta and can be considered as "reported site/site to report" for its national relevance for all these species; furthermore, interesting data on Tringa glaereola and Calidris temminckii were collected. The analysed shorebird community has been represented by a total of 16 different species, but mainly from Numenius arquata $33 \%$ of the total number of shorebirds observed), Charadrius alexandrinus $(24 \%$ of the total) and Calidris alba $(20 \%$ of the total). It was secondarily represented by Calidris alpina ( $7 \%$ of the total) and, to a lesser extent, from other species ( $16 \%$ related to 8 different species). The estimate of 2-6 ind. of Charadrius hiaticula during the decade is a relevant data, considering the last estimate of 7 ind. for the whole Sicilian oriental coast (Corso, 2005) and the maximum of 13 ind. reported for 2006-2010 for Saline di Priolo, Syracuse (Zenatello et al., 2014) and 9-34 ind. for Saline di Trapani (Trapani) for 2013-2016 (Surdo, 2016). The local wintering population of Charadrius alexandrinus in this relatively small area represented for 2011-2020 about 9\% of the whole Sicilian wintering population of 200-400 ind. standing to the last available regional estimate (Biondi \& Pietrelli, 2011). Despite the fact that Simeto's mouth represented in the past the most important wintering site for this species in the east coast of Sicily (Baccetti et al., 2002), with 120-150 ind. reported for 1990-2004 (Corso, 2005), it showed an alarming decrease of about $-80 \%$ for the whole Catania's Gulf and was never observed near Simeto's mouth, probably due to the sharp erosion of the beach and the strong anthropogenic disturbance. This data, unfortunately, reflects the regional and national negative trend of the species remarked by many authors (Biondi \& Pietrelli, 2011; Surdo \& Barbera, 2016); a decrease of -70\% is also reported for Sicilian breeding population (Surdo $\&$ Matteucci, 2016). The Calidris alba population represented $4.4-4.6 \%$ of the national wintering population and together with 40-65 ind. reported for Gela's Gulf (Zafarana, 2017), represented in total for 2011-2016 about $15 \%$ of the whole national wintering population (Zenatello et al., 2014): it confirms Sicily as one of the most important regions in Italy for wintering of Calidris alba. The estimated 25-55 ind. of Numenius arquata in 
Tab. 1 - List of species observed and related max. number per year, estimation, 5-years average $(\overline{\mathrm{X}})$, median $(\mu \mathrm{e})$ and standard deviation (SD) both for 2011-2015 and 2016-2020. The Mann-Whitney U Test was applied to compare differences between the first and the second five-years period, and being for each species $\mathrm{P}>$ $0.05, \mathrm{H}_{0}$ (null hypothesis) is confirmed: there is no a relevant difference between the distributions of the data samples. / Elenco delle specie osservate e relativo numero massimo per anno, stima, media quinquennale $(\bar{X})$, mediana ( $\mu$ e) e deviazione standard (SD) per il periodo 2011-2015 e 2016-2020. Il Test U di Mann-Whitney è stato applicato per confrontare le differenze tra il primo e il secondo quinquennio, ed essendo per ognuna delle specie $\mathrm{P}>0,05, \mathrm{H}_{0}$ (la nostra ipotesi nulla) è confermata: non esiste una differenza rilevante tra le distribuzioni dei due campioni di dati.

\begin{tabular}{|c|c|c|c|c|c|c|c|c|c|c|c|c|c|c|}
\hline \multirow{2}{*}{ SPECIES } & \multicolumn{10}{|c|}{ MAX NUMBER RECORDED PER YEAR } & \multirow{2}{*}{$\begin{array}{c}\overline{\mathbf{X}} / \mu \mathrm{e} \\
2011-15\end{array}$} & \multirow{2}{*}{$\begin{array}{c}\overline{\mathbf{X}} / \mu \mathrm{e} \\
2016-20\end{array}$} & \multirow{2}{*}{$\begin{array}{c}\text { EST. } \\
\text { 2011-15 }\end{array}$} & \multirow{2}{*}{$\begin{array}{c}\text { EST. } \\
2016-20\end{array}$} \\
\hline & 2011 & 2012 & 2013 & 2014 & 2015 & 2016 & 2017 & 2018 & 2019 & 2020 & & & & \\
\hline Haematopus ostralegus & 1 & 1 & 1 & 0 & 0 & 0 & 0 & 0 & 0 & 0 & $\begin{array}{c}0.6 / 1 \\
\mathrm{SD} \pm 0.55 \\
\end{array}$ & $\begin{array}{c}0 / 0 \\
\mathrm{SD} \pm 0.00 \\
\end{array}$ & $0-1$ & $\mathbf{0}$ \\
\hline Charadrius dubius & 0 & 0 & 0 & 0 & 2 & 0 & 1 & 0 & 4 & 0 & $\begin{array}{c}0.4 / 0 \\
\mathrm{SD} \pm 0.89\end{array}$ & $\begin{array}{c}1 / 0 \\
\mathrm{SD} \pm 1.73\end{array}$ & $0-2$ & $1-5$ \\
\hline Charadrius hiaticula & 1 & 4 & 3 & 3 & 6 & 2 & 2 & 6 & 1 & 3 & $\begin{array}{c}3.4 / 3 \\
\mathrm{SD} \pm 1.82\end{array}$ & $\begin{array}{c}2.8 / 2 \\
\mathrm{SD} \pm 1.92\end{array}$ & 3-6 & $2-6$ \\
\hline Pluvialis squatarola & 2 & 0 & 0 & 6 & 0 & 1 & 2 & 6 & 7 & 7 & $\begin{array}{c}1.6 / 0 \\
\mathrm{SD} \pm 2.61\end{array}$ & $\begin{array}{c}4.6 / 6 \\
\mathrm{SD} \pm 2.88\end{array}$ & $1-5$ & $2-7$ \\
\hline Calidris alba & 24 & 25 & 27 & 8 & 24 & 25 & 17 & 28 & 24 & 21 & $\begin{array}{c}21.6 / 24 \\
\mathrm{SD} \pm 7.70\end{array}$ & $\begin{array}{c}23 / 24 \\
\mathrm{SD} \pm 4.18\end{array}$ & $20-28$ & $20-30$ \\
\hline Calidris minuta & 3 & 2 & 3 & 4 & 1 & 0 & 0 & 0 & 0 & 0 & $\begin{array}{c}2.6 / 3 \\
\mathrm{SD} \pm 1.14 \\
\end{array}$ & $\begin{array}{c}0 / 0 \\
\mathrm{SD} \pm 0.00 \\
\end{array}$ & $2-5$ & $\mathbf{0}$ \\
\hline Gallinago gallinago & 0 & 0 & 0 & 0 & 1 & 1 & 0 & 1 & 4 & 4 & $\begin{array}{c}0.2 / 0 \\
\mathrm{SD} \pm 0.45\end{array}$ & $\begin{array}{c}2 / 1 \\
\mathrm{SD} \pm 1.87 \\
\end{array}$ & $0-1$ & $1-5$ \\
\hline Numenius arquata & 25 & 39 & 35 & 10 & 67 & 33 & 55 & 43 & 31 & 26 & $\begin{array}{c}35.2 / 35 \\
\mathrm{SD} \pm 21.00\end{array}$ & $\begin{array}{c}37.6 / 33 \\
\mathrm{SD} \pm 11.52 \\
\end{array}$ & $25-45$ & $30-50$ \\
\hline Actitis hypoleucos & 1 & 0 & 0 & 0 & 1 & 0 & 1 & 1 & 2 & 2 & $\begin{array}{c}0.4 / 0 \\
\mathrm{SD} \pm 0.55\end{array}$ & $\begin{array}{c}1.2 / 1 \\
\mathrm{SD} \pm 0.84\end{array}$ & $0-1$ & $1-3$ \\
\hline Tringa erythropus & 0 & 0 & 0 & 0 & 0 & 0 & 0 & 0 & 8 & 5 & $\begin{array}{c}0 / 0 \\
\mathrm{SD} \pm 0.00 \\
\end{array}$ & $\begin{array}{c}2.6 / 0 \\
\mathrm{SD} \pm 3.71 \\
\end{array}$ & $\mathbf{0}$ & $0-8$ \\
\hline Tringa nebularia & 0 & 0 & 0 & 0 & 0 & 0 & 0 & 4 & 0 & 2 & $\begin{array}{c}0 / 0 \\
\mathrm{SD} \pm 0.00 \\
\end{array}$ & $\begin{array}{c}1.2 / 0 \\
\mathrm{SD} \pm 1.79 \\
\end{array}$ & $\mathbf{0}$ & $1-4$ \\
\hline
\end{tabular}

the area most likely represent the whole wintering population of Catania's Plain, since it was already estimated in the past at 20-50 ind. in total for the period 1989-1997 (Ciaccio \& Priolo, 1997) and subsequently at around 67-180 ind. for the whole oriental coast (Corso, 2005). Wintering individuals mainly belong to the subspecies $N$. a. orientalis and, to a lesser extent, to $N$. a. arquata (Serra et al., 1997). Pluvialis squatarola in the area have decreased in comparison to the estimate of 12-31 ind. reported for the past years (Corso, 2005), when this area was considered the most important wintering-site for the species in Sicily (Iapichino \& Massa, 1989; Lo Valvo et al., 1993). This is probably another consequence of the strong erosion and habitat degradation of River Simeto's mouth. Recorded numbers of Calidris alpina and Calidris minuta are not relevant if compared to wintering population of other Sicilian localities, such as Saline di Trapani (Zenatello et al., 2014; Surdo, 2016; Surdo, 2018) and in any case showed a decrease for the Simeto's area (Corso, 2005). Species as Tringa totanus, Tringa nebularia, Tringa glareola, Tringa erythropus, Gallinago gallinago and Calidris temminckii cannot be considered closely related to the use of sandy coast for wintering and were indeed observed exclusively in the freshwater stream mouths and never along the shoreline. Despite this, it is important to highlight the relevance of Torrente Acquicella's mouth as wintering-site for Calidris temminckii, for which no records are reported for winters 2006-2010 in Sicily (Zenatello et al., 2014) and a maximum of 15-33 ind. was observed in Saline di Trapani in January 2019 (Surdo, 2019b). Likewise, it is an important site for Charadrius dubius, for which 
only 6-7 ind. are reported for the whole oriental coast for 2006-2010 (Zenatello et al., 2014) and maximum of 7 ind. in Saline di Trapani in late December 2018 (Surdo, 2019a). Just for its importance, Aquicella's mouth needs of basics protection management strategies (e.g. fencing), and specific actions of habitat restoring, communication, conservation education, regulation through local acts and laws (e.g. controlling fishing, dogs and other local threats), improving skill in volunteers, citizen management actions, etc... The observation of 3 ind. of Tringa glareola at the mouth of Canale Forcile is also interesting, since the species is only reported as wintering for the area of Mazara del Vallo (Trapani) and Saline di Trapani with 1-3 ind. (Zenatello et al., 2014; Surdo, 2016; Surdo, 2018; Surdo et al., 2018).

All the species listed and individuals observed were not evenly distributed along the transects: Transect 2 has been much more rich in species and number of individuals than the others, accounting for as much as $82 \%$ of the total of shorebirds observed. Specifically, the richest location has been the mouth of Canale Arci (Transect 2 ), where we observed $47 \%$ of the total shorebirds and 8 different species. Exactly the opposite is the situation of River Simeto's mouth, where less than 3\% of the total shorebirds were observed, and, in general, Transect 3 which resulted the poorest one. All the information related to the transects richness are included in Table 2.

\section{SYNECOLOGY}

Sandy coasts also represent a unique occasion for biological assemblages (McLachlan \& Brown, 2006), as it happens for the different shorebird species. Statistically, on a total of 266 records, the preference to associate with other species forming unique hetero-specific flocks, usually of 2 or more different species is relevant, as reported in Table 3.

Chi Square's Test $\left(\chi^{2}\right)$ was applied to verify if the frequencies of interspecific associations are purely random (null hypothesis, $\mathrm{H}_{0}$ ) or if they have a statistical relevance $\left(\mathrm{H}_{1}\right)$. Being: $\chi_{5}^{2}=231.6, \mathrm{P}<0.01$, we can confirm that the tendency to associate in groups of 2-3 different species is highly relevant. The commonest association observed has been between Charadrius alexandrinus and Calidris alba, with 42 records on a total of 266 , and between $C$. alexandrinus and C. hiaticula, with 25 records. Calidris alpina was never recorded alone and mainly associated to $C$. alba with 16 records. Association of 3 (or more) species were commonly recorded as well, mostly $C$. alexandrinus, C. alba and C. hiaticula (22 records, Fig. 6) or C. alexandrinus, $C$. alba and $C$. alpina (15 records). The species more frequently observed alone, without any association to others, were instead C. alexandrinus (13 records) and Numenius arquata (9 records). The complete list of associations observed is showed in Table 4.

Tab. 2 - Distribution of shorebirds along the 4 transects monitored and relative percentages of presence. / Distribuzione dei limicoli lungo i 4 transetti monitorati e relative percentuali di presenza.

\begin{tabular}{|c|c|c|c|c|}
\hline TRANSECT & LOCATION & $\begin{array}{l}\text { N. OF SPECIES } \\
\text { OBSERVED }\end{array}$ & \begin{tabular}{|l|}
$\begin{array}{l}\text { N. INDIVIDUALS } \\
\text { OBSERVED }\end{array}$ \\
\end{tabular} & $\begin{array}{l}\text { \% INDIVIDUALS } \\
\text { ON THE TOTAL }\end{array}$ \\
\hline \multirow{4}{*}{ Transect 1} & Torrente Acquicella's mouth & 6 & 113 & 3.6 \\
\hline & Canale Forcile's mouth & 5 & 14 & 0.4 \\
\hline & Other locations & 2 & 4 & 0.1 \\
\hline & Subtotal & 8 & 131 & 4.1 \\
\hline \multirow{4}{*}{ Transect 2} & Colonia Don Bosco & 5 & 1021 & 32 \\
\hline & Canale Arci's mouth & 8 & 1505 & 47.5 \\
\hline & Other locations & 5 & 85 & 2.7 \\
\hline & Subtotal & 8 & 2611 & 82.2 \\
\hline \multirow{4}{*}{ Transect 3} & Simeto's mouth & 7 & 92 & 2.9 \\
\hline & Gornalunga's mouth & 0 & 0 & 0 \\
\hline & Other locations & 0 & 0 & 0 \\
\hline & Subtotal & 7 & 92 & 2.9 \\
\hline \multirow{4}{*}{ Transect 4} & San Leonardo's mouth & 6 & 337 & 10.6 \\
\hline & Agnone's beach & 0 & 0 & 0 \\
\hline & Other locations & 0 & 0 & 0 \\
\hline & Subtotal & 6 & 337 & 10.6 \\
\hline \multicolumn{3}{|r|}{ TOTAL } & 3171 & 100 \\
\hline
\end{tabular}


Tab. 3 - The Chi Square's Test confirmed, on a total of 266 records, a relevant trend to form flocks of 2 species. / Il test del Chi Quadrato ha confermato, su un totale di 266 osservazioni, una tendenza rilevante da parte delle singole specie a formare associazioni di 2 specie diverse.

\begin{tabular}{|l|l|c|c|c|c|c|}
\hline FREQUENCY OF ASSOCIATION \\
\hline Number of co-occurring species & 1 & 2 & 3 & 4 & 5 & 6 \\
\hline N. of records & 59 & 120 & 60 & 24 & 2 & 1 \\
\hline Frequency $(\mathbf{n}=\mathbf{2 6 6}$ records) & $22 \%$ & $45 \%$ & $22.5 \%$ & $9 \%$ & $0.7 \%$ & $0.4 \%$ \\
\hline
\end{tabular}

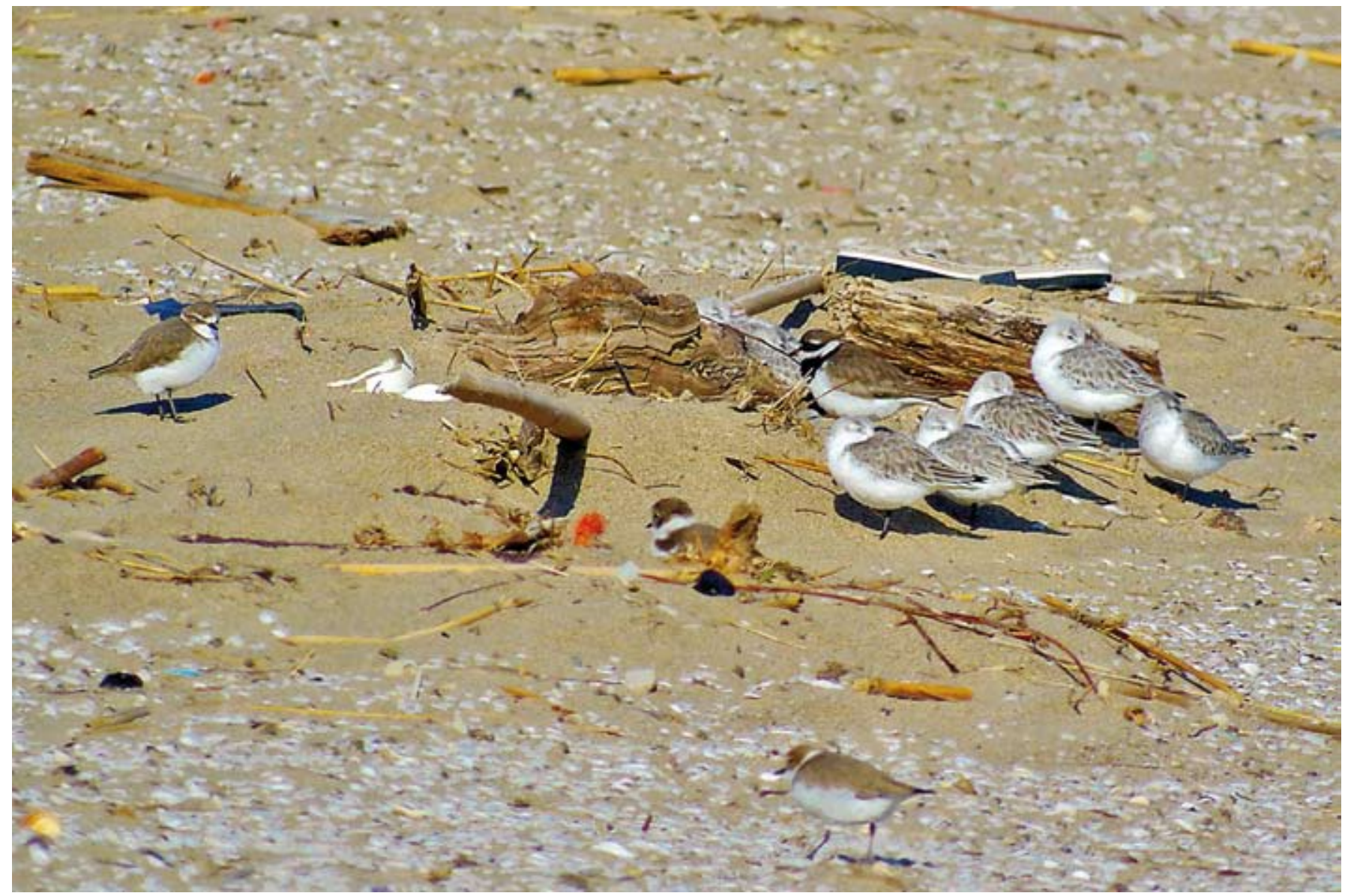

Fig. 6 - Hetero-specific flock composed of C. alexandrinus, C. alba and C. hiaticula. / Gruppo etero-specifico formato da C. alexandrinus, C. alba e C. hiaticula.

\section{CONCLUSIONS}

The presence of different freshwater streams is definitely essential for the wintering of shorebirds, whose highest numbers were recorded for every year near Canale Arci (Transect 2), where were observed $47 \%$ of the individuals recorded in total: Charadrius alexandrinus and Charadrius hiaticula showed specifically a very high regularity of wintering in this location.

The reasons of this higher concentration in such a limited area is probably linked to the eutrophic level of its waters. On the other hand, despite the area of Simeto's mouth being considered in the past one the most impor- tant wintering sites in Sicily, the strong erosion, already documented (Amore, 1993), in the last years deeply modified the shoreline of this stretch of coast, making it no more suitable for most of the shorebird species. Indeed, excluding Haematopus ostralegus, Tringa totanus, Tringa nebularia, Tringa erythropus, Gallinago gallinago and Actitis hypoleucos, no other species were ever observed in 2011-2020 in this area, and in any case less than the $3 \%$ of the shorebirds recorded. Generally, most of the shoreline of Catania's Gulf resulted strongly disturbed in all the winters of the study, regularly frequented by stray dogs, quads and motocross, fishers and subjected to actions of mechanical beach cleaning 
Tab. 4 - Interspecific associations with relative numbers of records and percentages on a total of 266 records. / Associazioni interspecifiche e relativo numero di osservazioni e frequenze osservate su un totale di 266 osservazioni.

\begin{tabular}{|c|c|c|}
\hline SPECIES ASSOCIATION & RECORDS & $\%$ ON TOTAL \\
\hline Charadrius alexandrinus \& Calidris alba & 42 & 15.8 \\
\hline Charadrius alexandrinus \& Charadrius hiaticula & 25 & 9.4 \\
\hline Charadrius alexandrinus, Calidris alba \& Charadrius hiaticula & 22 & 8.3 \\
\hline Calidris alba \& Calidris alpina & 16 & 6 \\
\hline Charadrius alexandrinus, Calidris alba \& Calidris alpina & 15 & 5.6 \\
\hline Calidris alba \& Numenius arquata & 12 & 4.5 \\
\hline Charadrius alexandrinus \& Pluvialis squatarola & 10 & 3.7 \\
\hline Charadrius alexandrinus, Calidris alba, Calidris alpina \& Charadrius hiaticula & 9 & 3.4 \\
\hline Charadrius alexandrinus, Calidris alba \& Numenius arquata & 7 & 2.6 \\
\hline Charadrius alexandrinus, Calidris alba \& Pluvialis squatarola & 6 & 2.2 \\
\hline Charadrius alexandrinus, Charadrius hiaticula \& Numenius arquata & 6 & 2.2 \\
\hline Charadrius alexandrinus \& Calidris minuta & 6 & 2.2 \\
\hline Other lesser and uncommon associations & 31 & 11.6 \\
\hline \multicolumn{3}{|l|}{ SPECIES OBSERVED ALONE } \\
\hline Charadrius alexandrinus & 13 & 4.9 \\
\hline Numenius arquata & 9 & 3.4 \\
\hline Charadrius hiaticula & 7 & 2.6 \\
\hline Calidris alba & 7 & 2.6 \\
\hline Pluvialis squatarola & 3 & 1.1 \\
\hline Other species observed alone & 20 & 7.5 \\
\hline TOTAL RECORDS & 266 & 100 \\
\hline
\end{tabular}

also during the winter. The coastline is often deeply anthropized, in some cases with illegal buildings just few meters away from the shoreline, which have contributed to its erosion (Lapiana \& Sparacio, 2010), such as along the coast of Agnone Bagni, Transect 4. Despite of all this human-related threats, the widest stretches (Transects 1-2 and mouth of San Leonardo, Transect 4) keep their value and are regularly used by Charadrius hiaticula, Charadrius alexandrinus, Pluvialis squatarola, Calidris alba, Calidris alpina and Calidris minuta. A more sustainable management of the shoreline habitat of Catania's Gulf is strictly recommended and it would certainly bring benefits also to the local community of wintering shorebird and, certainly, also to the breeding pairs of Charadrius alexandrinus (Ientile, 2011).

\section{Acknowledgments}

Our thanks go first to our friends that shared the monitoring on the field: Alberto Grimaldi, Giovanni Amato, Cristiano Caracciolo and Luca Ilahiane. A big thank to Renzo Ientile and Salvatore Surdo for their essential help, personal observations, advice and critical arrangement and to Fabio Marchioni for his final language review. A special thanks to the editor and anonymous reviewers of RIO (Rivista Italiana di Ornitologia), which believed on the merit of this survey, improving the first draft of the manuscript with useful comments and suggestions. Finally, PG wants to thank his wife Nadia, for her patience and for all the time he has spent in this study through to these years. 


\section{REFERENCES}

Amore C., 1993 - Formazione e dinamica delle facies sabbiose desertiche e costiere. Bollettino Accademia Gioienia di Scienze Naturali, Catania, 26: 29-49.

Baccetti N., Dall'Antonia P., Magagnali P., Melega L., Serra L., Soldatini C. \& Zenatello M., 2002 Risultati dei censimenti di uccelli acquatici svernanti in Italia: distribuzione, stima e trend delle popolazioni nel 1991-2000. Biologia e Conservazione della Fauna, 111: $1-240$.

Baccetti N., Fracasso G. \& COI (Italian Ornithological Committee - Rare Birds), 2020 - Checklist of the Italian Birds - updated 2019. Avocetta, 44.

Battisti C., 2014 - Bird assemblages on a Mediterranean sandy beach: a yearly study. Rivista Italiana di Ornitologia - Research in Ornithology, 84 (1): 23-28. < doi: 10.4081/rio.2014.214>

Bibby C. J., Burgess N. D., Hill D. A. \& Mustoe S. H., $2000-$ Bird Census Techniques. Second edition. Academic Press, London, UK.

Biondi M. \& Pietrelli L. (a cura di), 2011 - Il Fratino: status, biologia e conservazione di una specie minacciata. Edizioni Belvedere, Le Scienze (13).

Ciaccio A. \& Priolo A., 1997 - Avifauna della foce del Simeto, del lago di Lentini e delle zone umide adiacenti (Sicilia, Italia). Il Naturalista siciliano, 21: 309-413.

Chandler R., 2009 - Shorebirds of Northern Hemisphere. Christopher Helm, London.

Corso A., 2005 - Avifauna di Sicilia. L'Epos, Palermo.

Fowler J. \& Cohen L., 2010 - Statistica per Ornitologi e Naturalisti. Franco Muzzio Editore, Scienze Naturali Testi, Roma.

Galasso P., Aiello L. \& Bottini B., 2013 - Limicoli svernanti nel litorale sabbioso del Golfo di Catania 20102013. Il Naturalista siciliano, 37: 673-675.

Iapichino C. \& Massa B., 1989 - The birds of Sicily. British Ornithologists's Union, Check List ${ }^{\circ} 11$, London.

Ientile R., 2011 - Status di conservazione e fattori limitanti per la diffusione del Fratino (Charadrius alexandrinus) in Sicilia. Atti del Convegno Nazionale Fratino, Bracciano: 61-66.

Lapiana F. \& Sparacio I., 2010 - Le dune e gli ambienti umidi costieri della Sicilia. Tra passato, presente e futuro. Il Brigantino. Le guide del Brigantino, Palermo, 2.

Lo Valvo M., Massa B. \& Sarà M. (red.), 1993 - Uccelli e paesaggio in Sicilia alle soglie del terzo millennio. Il Naturalista siciliano, 17 (suppl. 1).

Massa B., 1978 - Studio dei Laro-limicoli di Sicilia (Aves, Charadriiformes). Atti II Convegno Siciliano di Ecologia, 71-114.

McLachlan A. \& Brown A. C., 2006 - The ecology of sandy shores. Academic Press, Burlington, MA, USA.

Serra L., Magnani A., Dall'Antonia P. \& Baccetti N., 1997 - Risultati dei censimenti degli uccelli acquatici svernanti in Italia, 1991-1995. Biologia e Conservazione della Fauna, Istituto Nazionale per la Fauna Selvatica, 101.

Surdo S., 2016 - Note sui limicoli svernanti nelle zone umide costiere della provincia di Trapani. Il Naturalista siciliano, 40: 33-49.
Surdo S., 2018 - Check-List degi uccelli della R.N.O. "Saline di Trapani e Paceco" con lista commentata dei non Passeriformes. Il Naturalista siciliano, 42 (1): 57109.

Surdo S. 2019a - Little Ringed Plover Charadrius dubius (N.7) In:, BIRD NEWS. Bazzi G. (ed.) Avocetta, 43 (2): 171. <https://doi.org/10.30456/AVO.2019207>

Surdo S. 2019b - Temminck's Stint Calidris temminckii (N.8) In: BIRD NEWS. Bazzi G. (ed.). Avocetta, 43 (2): 171. <https://doi.org/10.30456/AVO.2019207>

Surdo S. \& Barbera A., 2016 - Evoluzione della Laguna di Tonnarella (Mazara del Vallo, Trapani) e suo attuale valore ornitologico. Il Naturalista siciliano, 40: 4354.

Surdo S. \& Matteucci P. 2016 - Indagine comparativa sulla popolazione nidificante di Fratino Charadrius alexandrinus (Aves Charadriiformes) nelle saline della Provincia di Trapani. Il Naturalista siciliano, 40: 289-299.

Surdo S., Zafarana M.A. \& Barbera A., 2018 - Is the Wood Sandpiper Tringa glareola (Aves Scolopacidae) regular wintering in Sicily? Il Naturalista siciliano, 42 (1): 177-181.

Zafarana M. A., 2017 - Limicoli costieri (Aves Charadriiformes) nel Golfo di Gela (Sicilia). Il Naturalista siciliano, 41 (2): 161-182.

Zenatello M., Baccetti N. \& Borghesi F., 2014 - Risultati dei censimenti degli uccelli acquatici svernanti in Italia. Distribuzione, stima e trend delle popolazioni nel 2001-2010. ISPRA, Serie Rapporti, 206/2014. 